Rel. Stud. 35, pp. 307-32 I. Printed in the United Kingdom (C) I999 Cambridge University Press

\title{
The application of divine commands
}

\author{
JOSEPH SHAW \\ St Benet's Hall, University of Oxford, Oxford $O X_{I}{ }_{3} L \mathcal{N}$
}

\begin{abstract}
Divine commands are typically held, by theists, to be made not only at the foundations of morality, but also in an 'everyday' setting, when there are already moral considerations applicable to the addressee(s). My aim is to show how a particular command could relate to these pre-existing moral considerations, if it is more than just a repetition of them. If it is right that an action be obligatory, wrong or supererogatory, why would God want to change its status? Anyone can make a normative difference by giving information, making co-ordination proposals, or transferring rights, and it is clear why these actions will sometimes by worthwhile. The problem must be focused on when God makes a moral difference directly, using a 'special moral authority', when His commands are efficacious qua commands. Using this authority, God can perfect imperfect duties, which may make it easier to carry them out. He can extend duties, to make sure more value is produced. He can allocate sacrifices, which can be carried by anyone. And He can resolve conflict games, to everyone's benefit. This explains why God should issue commands in the way that theists typically represent him as doing.
\end{abstract}

I

In the recent upsurge of interest in divine command theories of ethics, the focus has usually been on the foundations of morality, and the question of whether all or some basic moral principles obtain purely by virtue of divine commands. In this paper I wish to consider divine commands ${ }^{1}$ in an everyday setting, leaving the question of foundations, as far as possible, open. The question I shall consider is a practical one: if, as theists typically and traditionally assume, God has the authority or right to issue binding commands, how might a divine command, made here and now, relate to and fit in with the moral considerations which would have operated in its absence?

I take it that, although this question is seldom raised explicitly by philosophers, theists typically and traditionally hold that a new command, as I say, made here and now, is both possible and can have an impact on what the addressee(s) ought to do, even though there were moral considerations already in existence which applied to the addressee(s). Whether or not all moral properties were originally created by, or are eternally dependent on, God, as some divine command theorists maintain, they exist now; my question is about how any commands God may make now should be seen as relating to them. When God is represented in scripture, for example, as

\footnotetext{
${ }^{1}$ For the purposes of exposition I shall refer to commands, rather than volitions (acts of will) in what follows. For a discussion of the difference talking about volitions might make, see Mark C. Murphy 'Divine command, divine will, and moral obligation', Faith and Philosophy, I5 (I998), 3-27.
} 
issuing a command, it is against a background provided by previous commands and moral principles independent of God, if there are any. If all moral properties are dependent upon God, then the very first command would not be made against such a background, but all subsequent commands would be.

A simple and unproblematic way of understanding how new commands relate to pre-existing considerations is that the former merely reiterate the latter, or apply the principles of the latter to the particular circumstances of the addressees of the new command. To show that a command is explicable by this account, it would be necessary to show that its content is derivable, in all its details, from pre-existing considerations. But there are, in the theistic tradition, many examples of commands made against a background of existing moral considerations which are clearly not reducible to them. I shall consider various complex cases below, but for the moment a good example is provided by ritual commands, which are to be found in practically all long-standing theistic traditions (including the Christian one). ${ }^{2}$ The ritual commands of, for example, the Hebrew Bible, are clearly intended to be morally binding, since their unjustified breach requires atonement and forgiveness from God, although the obligation may be very limited in whom, and for what time, it applies, and in its stringency. Now, it does not seem to be remotely plausible that everything which is laid down about, say, how sacrifices should be performed in Leviticus, can be accounted for as the application to particular circumstances of pre-existing moral considerations. And nor is it plausible that these detailed regulations had force prior to the time at which they were revealed. But theists who believe that these commands have or had genuine divine authority would not, typically, be embarrassed by these observations. They would, rather, reply that pre-existing considerations made such rituals fitting in the circumstances, but left room for God to ordain the details in more than one way; they would further add that it is one of God's attributes to be able, by commanding an action, to make it obligatory (in the 'all things considered' sense in which I shall use the term) when it had not previously been so. What I shall offer below is an account of how pre-existing considerations could both make a command 'fitting' and leave 'room' for it, without actually implying it.

It is worth emphasizing that such an account is necessary even to a divine command theorist who claims that evaluative moral properties (moral properties concerning value), and not only deontic moral properties (moral properties concerning obligation), depend on God's command. ${ }^{3}$ For if it is up to God to establish moral properties of any kind, and He actually does

\footnotetext{
${ }^{2}$ For example, Matthew 28.19 and I Corinthians Ir.24.

${ }^{3}$ For the stronger view, see Murphy 'Divine command, divine will, and moral obligation', I 7 ; for the weaker, see Robert M. Adams 'A modified divine command theory of ethical wrongness', reprinted in his The Virtue of Faith (New York NY: Oxford University Press, 1987), esp. 107 and I 5.
} 
so, then those moral properties will continue to exist until God abolishes them. If $\mathrm{He}$ commands that humans not kill except in circumstances $C, \mathrm{He}$ cannot then command, in a particular instance, that they kill in circumstances other than $C$ without repealing or revising the moral principle established by the first command. In this way, the first command establishes a background for the second. It would be odd to say that each new command requires or implies a special derogation from otherwise universal moral principles, and in fact, as I shall argue in detail below, there is no need to say this. What seems to be happening, rather, as I have already suggested, is that pre-existing considerations leave open a space for new commands. But they do so having established a system of duties and values which God Himself endorses, since, being rational, omniscient, and good, He endorses all genuine duties and values, whether created by Him or not. As Thomas Aquinas puts it in his own terminology, divine law can 'add to' natural law. How, then, to repeat, do new commands fit in with these pre-existing duties and values?

There is an apparently powerful argument that they cannot. Suppose that, circumstances being as they are, the balance of reasons is such that agent $A$ should $\phi$. Suppose further that God has the option of bringing it about that $A$ be obliged not to $\phi$. If He commanded $A$ not to $\phi$, and if, as I shall assume, the theist is correct in thinking that God has the authority to issue binding commands, a new and decisive reason for action would have been created, with the result that the balance of reasons is now such that $A$ is obliged not to $\phi$. The objection is that it is hard to see how, in doing this, God would Himself be acting for good reasons. If it is for the best, according to reasoning which God endorses, that $A$ be obliged to $\varphi$, why should God not want $A$ to be obliged to $\phi$ ? There seems to be no reason. This being so, it follows that God will never issue commands, once a system of reasons for action is up and running, with the result that the doctrine that He has the authority to do so will be pointless at best, and the use of that doctrine to explain divine commands in scripture and elsewhere will be doomed to failure.

At its broadest, the objection questions whether God would ever have good reason deliberately to change any of the normative circumstances of a moral agent. To answer this objection I will expound various categories of cases in which God would have good reason to effect such normative changes; the hope is that all cases of divine commands which theists would typically and traditionally be inclined to accept and defend will fall into one or more of these categories. The treatment will not be exhaustive, but is intended to give an impression of the resources available to the theist in explaining the point of particular divine commands. The cases will be categorized according to the different ways that God can bring the normative changes about, and the different kinds of change He can make.

\footnotetext{
4 Thomas Aquinas Summa Theologica, Ia 2ae 95.5 Responsio.
} 
In this section I shall describe five ways in which God can make a normative difference to human agents; furthermore, it should be clear that it will sometimes be worthwhile for God to make a normative difference in each of these ways. The first kind of case is perhaps most straightforward. He can simply act, other than in a speech-act, in such a way that some possible actions open to an agent become more or less value-generating than they would have been otherwise. By stopping the rain, making the roads passable, God can bring it about that an action of a doctor, to visit a village, is moved from the category of the morally neutral (because impossible) or supererogatory (if very difficult), or wrong (if, thanks to the difficulty, it would be a waste of time needed for other things), to being obligatory. The doctor will, as a result of God's action, have a duty which he would not otherwise have had.

In a second kind of case God can do the same thing by a speech-act, informing certain persons of non-moral facts. If God informs the villagers of the doctor's whereabouts, enabling them to find him, He can make an action of the doctor's, of treating them, obligatory, when it would previously have been neutral, supererogatory, or wrong, for reasons parallel to the ones in the previous case. As before, God can, in this way, bring about an obligation on the doctor he did not have before.

It is clear why it will sometimes be a good thing for God to make the normative difference described in cases of these kinds, which is a difference in the deontic status of actions. It is equally clear in the next three categories, which are moreover closer to the paradigmatic cases of God making a normative difference, inasmuch as they involve speech-acts which can take the grammatical form of commands. That is to say, in these cases it will often be natural for God to use the imperative. These can make three different kinds of normative difference, corresponding to the three normative concepts of blame, value, and deontic status.

In the third kind of case, divine speech-acts can make a normative difference with regard to blame by informing or reminding agents of moral truths. For example, the pilot of a crashing plane may have the option of steering towards sparsely populated land on which to crash, or of allowing the plane to crash on a densely populated town centre. If he is informed of his duty to do the former, of which he had been ignorant (or forgetful), the blameworthiness of the options has been changed. The pilot would, after the speech-act, be more blameworthy for choosing the second option than he would have been if the speech-act had not been made, since he would not have ignorance as even a partial defence.

The speech-act's reduction of the agent's ignorance will not effect the number of deaths that each of the two options would be likely to bring about. 
It may, however, effect the value of the pilot's act of choosing the second option, if a deliberate bad action is a worse thing, in itself, than an outwardly identical action done in some degree of ignorance of its moral badness. But this aspect of an action's value follows from the deontic status of the action and the agent's knowledge, and cannot be part of an explanation of why it is wrong or blameworthy; I shall ignore it in talking about the 'value' of an action (the value an action might bring about) below. The important point is that the blameworthiness of taking the second option has been changed without changing its 'objective' deontic status (whether it was obligatory, wrong, neutral, or supererogatory, all things being properly considered), and without changing its 'value', in my restricted sense.

It is worth noting that a very large number of the commands in the theistic tradition fall into this category. If the Hebrew Bible is anything to go by, God is not afraid of repeating Himself, and so we should not expect every command to make a difference to the objective deontic status of actions; many simply inform or remind the addressees of what that status already was, whether established by a previous command or by moral principles independent of God. This has encouraged some philosophers, such as the Socrates of Plato's early dialogues, ${ }^{5}$ and Kant, ${ }^{6}$ to embrace the informative role of divine commands as the only legitimate one; this, however, is an unnecessary limitation, as I hope will emerge in the course of this paper.

The fourth kind of case is where a speech-act can change the relative value of different options open to an agent, in the context of a co-ordination problem. In a co-ordination problem, there is more than one agent and more than one option each agent could take, and 'The outcomes the agents want to produce or prevent are determined jointly by the actions of all the agents'.? In a pure co-ordination problem there is no conflict of interest, so it is in the interests of each agent to produce a combination of actions of a kind desired by all agents. This 'equilibrium combination' can, however, take many forms. In one game it might be equally good if everyone chose option I, or if everyone chose option 2, or if everyone chose option 3, and equally bad if different people chose any combination of different options. A co-ordination can be achieved (other than by chance) by anything which creates what David Lewis calls 'concordant mutual expectations'. ${ }^{8}$ If one agent expects other agents to go for option I, in my example, he will do the same.

Once one possible equilibrium combination is seen to stand out in some way, ${ }^{9}$ the mere increased likelihood of other agents pursuing it increases the 'expected value' of the action of pursuing it; the 'expected value' of such an action being the value of the successful co-ordination multiplied by the

\footnotetext{
${ }^{5}$ See the Apology, $3_{\mathrm{I}} \mathrm{D}$ and Phaedo, 6oE-6 $\mathrm{I}$ B, and Gregory Vlastos Socrates: Ironist and Moral Philosopher (Ithaca NY: Cornell University Press, I991), I57-1 78.

${ }^{6}$ Immanuel Kant Religion Within the Limits of Reason Alone ( I 793), Bk I, §4 and passim.

7 David K. Lewis Convention: A Philosophical Study (Cambridge MA: Harvard University Press, I969), 8.

8 Ibid., 25

${ }^{9}$ Ibid., 35 .
} 
probability of its being achieved by this action. This being so, what was previously a neutral choice between options of equal (expected) value becomes a choice in which one option is more valuable than any other; this may have the result that each agent is morally obliged to take it, and would therefore be blameworthy for not doing so.

Divine speech-acts can serve as 'co-ordination proposals', that is, proposals as to which equilibrium agents should choose, creating concomitant mutual expectations merely by picking one equilibrium out. ${ }^{10}$ By doing so, they will increase the expected value of the action of choosing the option picked out, and as indicated this may itself be enough to make it obligatory. On one interpretation, the Fourth Commandment of the Decalogue, ${ }^{11}$ to keep holy the Sabbath day, is an example of this. John Duns Scotus points out that what he calls 'Natural Law' (which for our purposes can be taken as simply the sum of pre-existing moral considerations) ' $\ldots$ is affirmative insofar as it prescribes that some worship be given to God at a specific time, but so far as the specification of this or that time goes, it does not pertain to the law of nature strictly speaking'. ${ }^{12}$ This is precisely the kind of 'space' left by preexisting moral considerations which is required for new commands. If collective worship (at least in a given community) is a good thing, then everyone has a reason to worship on the same day of the week as everyone else. They will not converge on one day by thinking about the moral considerations in the absence of a command, however, since the choice of day is arbitrary. Each day of the week is a 'co-ordination equilibrium'; none is superior to any other, and none stands out in any way. If God makes, as in the Fourth Commandment He is supposed to have made, a suggestion of which it should be, this will constitute a co-ordination proposal. By virtue of increasing the likelihood of people worshipping on that day, it will increase the value of the act of worshipping then, relative to that of worshipping on any other day, with the consequences for deontic status and blame noted above.

In the fifth kind of case, a speech-act can change the deontic status of an action without changing the value that the action will bring about, if it gives the addressee(s) a right or a permission. If God has the right to the use and enjoyment of a piece of property, He may either transfer the right in toto to a human, or He may permit a human to use and enjoy the property until further notice, which is a more limited right. Sometimes, the holder of a right does not have the right to transfer it to another party, or to permit another party to do all the things which the right allows the right-holder to do. At least some of the rights attached to political office, and conjugal rights, spring to mind as examples of this. One marginal case might be God's right to

\footnotetext{
${ }^{10}$ Christopher McMahon suggests that promises can be co-ordination proposals in a parallel way, in his 'Promising and co-ordination', American Philosophical Quarterly, 26 (I 989), 239-247.

${ }^{11}$ Exodus 20.8, Deuteronomy 5.I2.

12 Scotus Ordinatio III, suppl. dist. 37, in Allan B. Wolter (ed.) Duns Scotus on the Will and Morality (Washington DG: Catholic University of America Press, I986), 275.
} 
punish a malefactor. It might not be possible for Him to pass the right on to a creature, but still be possible for Him to permit a creature to carry out the sentence.

In any case, once an agent has a new right, a range of actions open to the agent which were previously wrong become permissible: their deontic status has been changed, although the value of the actions has remained the same. The actions also cease to be blameworthy, as a consequence of the change in deontic status.

If, as is reasonable to assume, God has extensive rights over the created universe, such as ownership rights over what He has made and the right to punish wrongdoing, then the potential for His transferring rights and giving permissions will be wide. For instance, Genesis $9.2-3$ is pretty explicitly a permission to kill animals. John Selden derived political consequences from what he claimed was the donation of the universe to Adam in Genesis I.28;13 more recently Baruch Brody has claimed, conversely, that the continuing ownership of the universe by God allows Him to establish any conditions on our using it which He wishes. ${ }^{14}$ This must be distinguished from claims that God owns human beings, and therefore has a right to command them as His slaves. ${ }^{15}$ This would enable God to give direct orders, rather than placing conditions on the granting of rights to the usage of creation. I shall discuss the 'special moral authority' this implies below.

It might be argued that God's continuing ownership of the universe is an unverifiable historical contingency, and therefore an unsatisfactory basis for any substantive moral claims. ${ }^{16}$ On the other hand, it seems reasonable to accept that God has the right to take a human's life, and this forms the basis for a traditional explanation of the command to Abraham to sacrifice his son Isaac in Genesis 22.2. ${ }^{17}$ Aquinas explains God's right as deriving from a general right to punish, since Isaac was under sentence of death on account of original sin. ${ }^{18}$ Alternatively, it might be explained in terms of a property right, if God's original gift of life to each person is for just as long as God sees fit. In either case, God could have granted Abraham the right to take Isaac's life. This is not done explicitly in the Genesis story, but in general a command or a request by one agent to another may be taken to imply any permission necessary to the rightful performance of the action commanded or requested, which is in the speaker's power to give. Thus, if I ask you to enter my house,

\footnotetext{
13 John Selden Mare Clausum (1652), $27 f f$.

14 'Morality and religion reconsidered' in Brody (ed.) Readings in the Philosophy of Religion (Englewood Cliffs NJ: Prentice Hall, i 974), esp. 6o i, note i 7.

15 Brody cites the Talmud Tractate Kedushim 22b, $30 \mathrm{~b}$ and John Locke; see the latter's Second Treatise on Government II, §6, and First Treatise on Government, ch. 4. The idea is shared by John Calvin in Institutes of the Christian Religion Bk III, ch. XIV, § I 5 .

16 See Robert Nozick Anarchy, State and Utopia (Oxford: Blackwell, I974), 287-289.

17 For example, Scotus Ordinatio III, suppl. dist. 37; Ad argumenta principalia, in Wolter Duns Scotus, 287.

18 Summa Theologica, ra 2ae 95.5 ad 2.
} 
I have implicitly permitted you to do so. In commanding Abraham to kill his son, God may therefore be taken to permit him to do so.

Of course, rights only relate to the permitted, and other factors must come into play to explain why Abraham was obliged to take steps to kill Isaac, if indeed he was, or even why he had reason to do so. But being granted a right can create an obligation, by making it true that certain options no longer infringe anyone's rights. To vary the example, if I am obliged to travel somewhere as quickly as legally possible, I may become obliged to drive just when someone gives me permission to use his car. The speech-act of permission can, in such a case, bring it about that I have an obligation which I had not previously had.

I I I

The reader may feel impatient with these examples, for two reasons. The first is that in none of the above cases is God doing something which human beings cannot do. Humans can perform actions which have the consequence that someone has a duty which he did not previously have, either in a speech-act or in some other way. They can give agents moral information, make coordination proposals, and give permissions, with the same normative consequences that these actions have when God does them. The second reason, which is related but not identical to the first, is that in none of the above cases does God seem to be using what we might call a 'special moral authority'. Instead of making normative changes directly, as we might expect, God seems, in these cases, to be manipulating the circumstances to which preexisting moral principles apply. For both these reasons, it may be said that these are not examples of what the fuss is all about: they are not examples of ex nihilo creation of moral properties, which the theist may be taken to believe in, and the objector to worry about.

Having said that, bearing in mind that in the latter three kinds of case there can be a divine speech-act in the grammatical form of a command, the categories cover a very large number of the commands accepted in the theistic tradition, including many of the most controversial ones; if this can be done without appeal to philosophically problematic notions of authority, that is to the good. The above examples also perform another service, since they show that claiming that God can make it morally permissible for Abraham to kill Isaac, for example, or that He can arbitrarily pick one day of the week out of all the others to be the day of worship and rest, is perfectly compatible with the denial that God has any special moral authority. The positions in the debate about divine commands must be defined with great care.

What is this 'special moral authority'? One way of expressing it might be to distinguish the changing of morally relevant circumstances to which pre- 
existing moral considerations apply, and establishing a new (or changing an old) moral principle. ${ }^{19}$ But this distinction is hard to uphold. For there is, according to the theist, a true moral principle or axiom that divine commands bring it about that a commanded action ought to be done. ${ }^{20}$ But if this is so, a particular command can be presented as the mere changing of a circumstance to which this pre-existing principle applies.

An alternative way of making the distinction is this. In the above examples, even when the divine action which brought about the normative change was a speech-act in the form of a command, its efficacy in making the normative change can be explained without use of the concept of a command. The normative changes were made by virtue of the speech-acts carrying moral information, or making a co-ordination proposal, or by giving a right. Although they may be 'commands' in a grammatical sense, and may be treated as commands by theists, they have the normative consequences they have not qua commands but qua informative, qua coordination proposal, or qua giving a right. (It is not enough to say that these jobs can be carried out by speech-acts not in the grammatical form of commands, because this is true of at least some commands which are exercises of God's special moral authority, namely implied commands.) But where God is exercising his special moral authority, the normative difference he makes in issuing a command cannot be explained except by reference to the fact that the speech-act at issue was a command.

To put it a different way, whether or not different options open to an agent contravene divine commands (qua commands) can be seen as another morally relevant circumstance of a case, alongside the agent's knowledge, the expected value of different options, and the rights which would be violated by different options. The above examples can be explained in terms of God manipulating the latter three circumstances of situations; it may be that other examples of divine intervention which result in normative changes can only be explained in terms of God's manipulation of the first.

It remains to the objector to say the following. Leaving aside the question of ignorance, which cannot effect the objective deontic status of actions, it is perfectly comprehensible that a change in the value of, and a change in what rights would be violated by, different options open to an agent, can make a difference to the agent's normative situation, including the agent's obligations. And if it is true that divine commands give an agent reasons for action, then it will be true that a change in which options contravene divine commands can make a difference to the agent's normative situation as well. But it is entirely incomprehensible that God should want to change an agent's normative situation in this way, without changing either the value of

\footnotetext{
19 Joseph Raz 'Voluntary obligations and normative powers II', Proceedings of the Aristotelian Society, suppl. $\mathbf{4}^{6}$ (1972), 79-102.

${ }^{20}$ Edward Wierenga The Nature of God (Ithaca NY: Cornell University Press, I 989), 228.
} 
options, or which options violate rights. To restate the original objection: if it is for the best, according to a consideration of both expected value and others' rights, that $A$ be obliged to $\phi$, why should God not want $A$ to be obliged to $\phi$ ?

A simple example will illustrate the point. Suppose that, circumstances being as they are, a mother has a duty to feed her hungry children. According to the theist, God has the option of changing the morally relevant circumstances to bring it about that she is not obliged to feed them. One way that He can do so is simply by commanding her not to feed them, which speechact will, the theist claims, give her a new and overriding reason not to do so. And He can do this without changing any of the other morally relevant circumstances of the case: without, for example, making alternative provision for the children, or giving the mother something more important to do. But surely, since it was for the best that she should have a duty to feed her children in the circumstances, there is no reason why God would want to relieve her of the duty without changing the circumstances which gave rise to it, namely, the circumstances connected to value and rights. If this point can be extended to all cases, God, being rational, omniscient, and good, would never exercise His special moral authority, and so no cases of divine commands will be explicable in terms of it. The objector may go on to conclude that commands per se are not a genuinely morally relevant circumstance after all.

My strategy will be to show, not that God can have good reasons to issue a command in the case just described, but to explore four more categories of cases in which it can be a good thing for God to effect a normative change solely by virtue of issuing a command, without changing the value of an option or whether it violates anyone's rights. The theist is not committed to saying that God will always have reason to command any arbitrary thing in any situation; all that is needed to answer the objection is to show that there are important cases in which the it can be worthwhile for God to use his special moral authority. In the following four kinds of case, I shall argue that it will be a good thing to change an action's objective deontic status without (let alone by means of) changing the amount of value it might bring about, or whether it violates anyone's rights. It will only be possible to bring about that change by the exercise of a special moral authority, and the change will only be explicable by reference to a command qua command.

IV

The first of my four examples of possible worthwhile exercises of a special moral authority is this. Going back to Scotus' example of the Fourth Commandment, the point of the command can be seen in a different way. Even 
if there were no co-ordination problem here - if collective worship were not a good-God might still have reason to make the duty of worship more specific and concrete than it was before. By doing so He would be making an 'imperfect' duty - a duty which can be performed in more than one way (more) perfect. ${ }^{21}$ In general, ritual commands fall into this category, since they specify how an imperfect duty of worship should be carried out. Sometimes it may be best for people to have the freedom to choose for themselves how to perform imperfect duties. But in other cases, especially as a temporary measure in the course of a moral education, it will be a good thing that they be perfected. This is because, as a matter of psychology, it is often easier to remember, and to get oneself, to worship on this day every week, and in this way, than it is to remember to worship at some time, and in some way. Universal moral principles cannot always make duties perfect, because, as with these examples, it is an arbitrary matter precisely how they are carried out. A person, but not a moral system, can make an arbitrary decision of the necessary kind; this decision will then have to be revealed to those to whom it applies, since there will be no way for them to work it out from first principles.

It is worth noting that, in this case, the command does not make morality any more demanding than it had been before: it just tells us how we are to set about fulfilling one of our pre-existing obligations. But the deontic status of actions has been changed. Previously neutral actions, which could have fulfilled the obligation, are now either obligatory, if commanded, or supererogatory, if possible as good actions additional to the fulfilment of the command, or wrong, if incompatible with the fulfilment of the command.

The second category is of cases in which a command makes a duty more stringent. In the absence of a command, Moses' duty to worship God, for example, might well have been sufficiently fulfilled by less than what God actually commanded him to do. In such cases, supererogatory actions are made obligatory.

God can ensure that a greater amount of good is achieved by making morality more demanding than it would otherwise be, and this gives Him a reason to do so. But if it is a good thing to make morality more demanding, it will be asked why it is not already that demanding. The answer is, first, that it may just be the case that morality is not very demanding, and not as demanding as it would be good for it to be. Second, it is often very difficult to interpret the stringency of duties, especially imperfect ones; it is therefore very difficult to blame people for doing less than it might be best for everyone to be required to do. Third, in issuing new commands God can adjust the stringency of a duty to circumstances, both of the addressee and of the people He has duties towards, in a way which it would simply be too complicated

${ }^{21}$ The terms 'perfect' and 'imperfect duties' were coined by Kant; see his The Metaphysics of Morals, Part II, §VII, KA 6.39o. 
for basic universal rules to do. It is the latter which may be at issue when the stringency of ritual requirements is varied over time.

The third category involves the allocation of sacrifices. What I have in mind is a case in which one person needs to do some task if a great good is to be attained, but where it does not much matter who, out of a range of possible agents, actually does it. In such a case, reflecting on the pre-existing moral considerations cannot help us to specify the agent, since there is no non-arbitrary way of picking one out. It would not make sense, either, for everyone to be obliged to do it, in cases where duplicated effort is particularly costly. Again, being obliged to do it unless and until someone else does it will solve the problem only where there is perfect communication. It is normally supererogatory to step forward to do such a task, and it was partly with reference to this kind of case that $\mathrm{J}$. O. Urmson revived the concept of supererogation. As he says: '... it would be quite ridiculous for everyone, however circumstanced, to be expected to go off and nurse lepers. But it would be absurd to try and formulate complicated rules to determine in just what circumstances such an action is a duty'. ${ }^{22}$ Urmson thought that it would never be right to require such an action of an agent, and certainly it can never be required by universally applicable moral principles. But in the context of military commands, supererogatory actions are frequently made obligatory, and often it is very necessary that this happen, if, for example, a dangerous or unpleasant action must be done to save the whole group. An action, which it would have been supererogatory to volunteer to do, becomes obligatory for the person commanded to do it by someone in authority. By parallel, it may often be a good thing that God makes actions obligatory for one person to do, which were previously supererogatory for anyone in a particular group.

Sending prophets on missions is an example of the allocation of sacrifices. The pre-existing reasons God has for sending someone to a place might easily under-determine the choice of whom to send. In fact, since plausibly any one out of a large group of people would do equally well, the choice between them is not guided by reasons at all. What is guided by reasons is that God makes some choice, avoiding the irrationality of Buridan's ass, starving to death equidistant between two equally attractive piles of hay.

That ordinary theistic assumptions support this view can be seen in this way. If God had been simply informing Jonah, ${ }^{23}$ for example, of the urgency of the mission to Nineveh, Jonah would have been able to shift his obligations to, or share them with, anyone he had told (and convinced) of the value of preaching in Nineveh. But in fact other believers would be likely to reply that it was Jonah who had been commanded, and he alone who was obliged,

\footnotetext{
22 'Saints and heroes' in Joel Feinburg (ed.) Moral Concepts (Oxford: Oxford University Press, I969), 2 I 3 . 
not necessarily because he was the best man for the job but because God had chosen him.

Finally, the fourth category involves conflict games. The ranking of options by different agents to result in a conflict of interest can happen even when all parties are taking all relevant moral considerations into account, at least on some moral views. Derek Parfit gives an example of this, the 'Parent's Dilemma' Case 3, which is a version of the well-known Prisoner's Dilemma. ${ }^{24}$ Parents must decide whether to contribute to collective goods which benefit their own children, where the contribution itself takes some resources away from their children, or to undermine the collective goods by free-riding. If the needs of their own children create reasons for action for each parent, and if we assume that other moral considerations, such as fairness, are not powerful enough to alter the order of preferences, then a consideration of all reasons for action will result in each parent free-riding. This is because, from the point of view of benefiting their own children, each parent is better off free-riding regardless of what the others do, despite the fact that the situation of no-one free-riding is preferable, from the same point of view, to the situation of everyone doing so. This makes free-riding a 'dominant choice' ${ }^{25}$

How often such a conflict of moral interests could arise will depend upon how powerful moral considerations which are relative to each agent, such as the consideration of looking after one's own children, as opposed to children in general, are. This is a controversial matter, but if moral conflicts of this kind ever did occur, it would clearly be worthwhile for God to use His special moral authority. A command could create new reasons for action for each agent, strong enough to alter the order of the agents' preferences, and create a new dominant choice. A command to everyone in the game, to contribute to the collective goods, would make free-riding wrong, where it had been obligatory, and make contributing obligatory, where it had been wrong. This would result (in Parfit's simple case) in a new equilibrium, in which everyone would be better off, even in terms of looking after their own children.

What these four types of case, the perfection and extension of duties, the allocation of sacrifices, and the resolution of conflict games, have in common, is that the deontic classification of actions by pre-existing moral considerations is not 'for the best'. This may seem paradoxical, but in each case it is clear enough why it should be so: universally applicable moral considerations classify actions as they do, not only because it will be best that they be classified in that way, but because they are simply incapable of supplying arbitrary or complicated answers to practical problems. This is also at issue in the earlier case of co-ordination problems: the reason why coordination problems arise is that no amount of reflection on the morally

\footnotetext{
${ }^{24}$ Derek Parfit Reasons and Persons (Oxford: Oxford University Press, I 984), 97.

${ }^{25}$ See Lewis Convention, 34
} 
relevant circumstances, when these are limited to others' rights and the value of options, will give everyone the same, arbitrary answer.

I hope I have shown that there is a whole range of cases in which it can be worthwhile for God to exercise His special moral authority, and issue commands binding in themselves. Whether He will actually do so in a particular case is another matter; there are various reasons which might apply for leaving humans to solve their problems without commands to help them. But the typical and traditional theist claim is that God has, in the past, issued commands, and probably continues to do so, both to particular individuals and possibly also to groups through religious institutions. What I have said above should explain both what is held, by these theists, to be going on in such cases, and why God would have reason to act as they claim He does. To end, there are a number of loose threads that need to be tied up.

First, as mentioned at the start of this paper, a particular command may fall into more than one category. The sacrifice of Abraham presumably combines the perfection of an imperfect duty, to offer sacrifice, with a permission. Other ritual commands may perfect imperfect duties and as serve as co-ordination proposals, if it would be a good thing that everyone in a community worship in the same way as everyone else. If God has a special moral authority, it will make Him more effective in making co-ordination proposals, since people will have an extra reason to follow them. It may be worth noting that since this extra reason will typically have the result that each agent would choose (or ought to choose) the option picked out regardless of his expectations of others' actions, then the option commanded has become a dominant choice. This means that the agents are no longer interested primarily in co-ordination, so they are no longer, strictly, in a 'co-ordination problem'. ${ }^{26}$

Second, my account has been able to explain how pre-existing moral considerations could guide and justify God in issuing commands in an everyday setting. But this account will not be applicable where there are no moral considerations prior to the command, as will be the case with the 'foundational' commands mentioned at the start, according to those divine command theorists who claim that all moral properties derive from divine commands. I have not considered this case in this paper. Nor have I considered the less extreme situation of God adding deontic properties to a universe which has only evaluative properties. The problem I have, hopefully, gone some way to dissolving in an everyday setting remains active for

$$
{ }^{26} \text { Ibid., } 35 \text {. }
$$


these foundational cases. There are various options open to the theist with regard to them, which cannot be explored here. It may prove possible to explain how, in the second case, evaluative properties guided and justified God in creating deontic properties. ${ }^{27}$ It may be denied that either evaluative or deontic properties ever needed to be created ex nihilo. ${ }^{28}$ Or it may be denied that any account of God's reasons for action in the course of his creative activity needs to be given at all.

Third, God is not necessarily the only being with some kind of special moral authority. I have already mentioned in passing the parallel with military commands; in general, state authority is usually held to be able to perfect and extend duties, and to allocate sacrifices. Parental authority over children must do the same thing. Promising, also, apparently has the power to perfect imperfect duties, and to make supererogatory actions obligatory. ${ }^{29}$ They can do these things only by virtue of a special moral authority, as I have defined it. On the one hand, this may seem to diminish the uniqueness of God's position. But on the other, the parallels give support to the claim that the concept of a special moral authority makes sense, and has a genuinely worthwhile application. God's uniqueness remains, inasmuch as his authority is both universal and supreme.

Finally, the concept of special moral authority is inconsistent with the consequentialist principle that the action which produces the most value is obligatory. This is because a special moral authority gives an agent the power to vary the deontic properties of an action other than by varying its value. This, however, may be more of a problem for consequentialism than for my account, for two reasons. One is the parallels just mentioned with the state, parents, and promising. Consequentialists must reject or redescribe not only God's authority, but also give some explanation of how these other moral institutions can function without any special moral authority. ${ }^{30}$ The other is that many of the examples of the last section are counter-examples to the consequentialist principle. In those cases what an agent ought to do cannot simply be read off from what would bring about the most value, for the reasons discussed.

These are complex and controversial issues, and I can do no more here than indicate the direction from which a response might come.

\footnotetext{
27 For problems with this see John Chandler 'Divine command theories and the appeal to love', American Philosophical Quarterly, 22 (I985), 23 I-239.

28 See Richard Swinburne The Coherence of Theism (Oxford: Clarendon Press, I993), 2 ro.

29 That promising requires what I call special moral authority is supported by Joseph Raz 'Promises and obligations' in Hacker and Raz (eds.) Law, Morality and Society (Oxford: Clarendon Press, I977), 2 I0-228; Michael Robins Promising, Intending and Moral Autonomy (Cambridge: Cambridge University Press, I 984); and Geoffrey R. Grice The Grounds of Moral Fudgement (Cambridge: Cambridge University Press, I 967) 57-79. That they do not is argued by Neil McCormick 'Voluntary obligations and normative powers I' Proceedings of the Aristotelian Society suppl. 46 (1972), 59-78 (followed by Raz's reply, 79-102).

${ }^{30}$ There is a considerable literature on whether this is possible. Promising is discussed by Grice in The Grounds of Moral Fudgement, 57-63; the state is discussed by George Klosko in The Principle of Fairness and Political Obligation (Lanham MD: Rowman and Littlefield, I992), I57-1 74.
} 